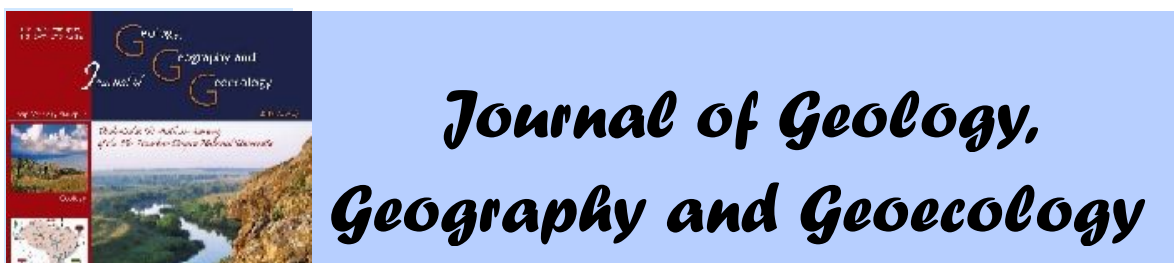

Journal home page: geology-dnu-dp.ua

\title{
Dynamics of ecological stability of small towns in Kyiv region
}

\author{
V. Yu. Yukhnovskyi, O. V. Zibtseva
}

National University of Life and Environmental Sciences of Ukraine, Kyiv, Ukraine, e-mail: yukhnov@nubip.edu.ua; yukhnov@ukr.net

Received 17.08.2018;

Received in revised form 21.08.2018;

Accepted 12.09.2018

Abstract. The purpose of this study is to provide a comprehensive assessment and comparative analysis of the ecological balance of territories of the three key small towns in Kyiv region: Boyarka, Vyshneve and Irpin, as well as tracking the dynamics of ecological stability of the towns' territories in the system of general planning. The following indicators of anthropogenic transformation and natural protection of urban areas were calculatedaccording to known methodsbased on data available from the towns' new Master Plans: coefficients of anthropogenic impact, anthropogenic transformation, nature protection, and ecological stability, absolute and relative tension of the ecological and economic state. The rationality of general planning in terms of ecological balance of urban areas is estimated. The study established that the territory of the town Irpin is characterized by moderate anthropogenic impact, while Boyarka and Vyshneve demonstrated a high level of anthropogenic impact. The total area of the environmental fund on the territory of cities ranges from $13.9 \%$ (Vyshneve) to $47.5 \%$ (Irpin) of the total area of their territories, which is insufficient in all cases. Currently, the territory of Irpin is the most balanced in comparison with other towns. Implementation of the new Master Plans of the cities will improve the ecological balance of the Boyarka and Irpin areas; improvement in Boyarka will be notably extensive due to the expansion of the city boundaries by a threefold increase in the town's area. The projected general development of Vyshneve will worsen the ecological balance of its territory, despite the foreseen expansion of its boundaries. The pressure from the ecological and economic status of the territories is not balanced by the degree of anthropogenic impact and the potential of the sustainability of nature. For the territory of towns, the potential for sustainability of nature is significantly exceeded and requires the expansion of the environment of a stabilizing group of lands. The areas of towns within the existing boundaries are environmentally unstable, the tensions in the ecological and economic conditions of the territories are not balanced, which testify to their ineffective organization. A significant correlation has been found between the calculated coefficients and the area percentage of the environmental fund of urban areas. The obtained data testifies to the expediency of using the indicated eco-geographical indicators within the system of general planning in order to optimize prospective solutions.

Keywords:urban landscape, anthropogenic impact, anthropogenic transformation of landscape, eco-geographical indices

\section{ин мік екологічної ст більності м лих міст иївщини}

\author{
. . хновський, . . ібцев \\ ціон льний університет біоресурсів і природокористув ння кр їни, иїв, кр їн, \\ e-mail:yukhnov@nubip.edu.ua; yukhnov@ukr.net
}

нот ція. етою дослідженняєкомплексн оцінк і порівняльний н ліз екологічної зб л нсов ності територій трьох м лих міст иївської обл сті - оярки, ишневого т рпеня з н лізом дин міки екологічної ст більності їх територій у системі генер льного пл нув ння. д ними енер льних пл нів міст розр хов но пок зники нтропогенного перетворення і природної з хищеності міських територій. ст новлено, що територія м. рпінь х р ктеризується помірним, міст оярк т

ишневе - високим нтропогенним н в нт женням. г льн площ екологічного фонду н території міст колив ється від 13,9 ( ишневе) до 47,5\% ( рпінь), що в усіх вип дк х є недост тнім. ериторії міст в чинних меж х екологічно нест більні, н пруженість еколого-господ рського ст ну територій не зб л нсов н . е ліз ція енер льних пл нів міст покр щить екологічну зб л нсов ність територій оярки т рпеня, причому оярки - к рдин льно з р хунок трикр тного розширення межі міст . рогнозов ний генер льним пл нув нням розвиток м. ишневе погіршить екозб л нсов ність його території не зв ж ючи н передб чене ї̈ розширення. иявлено високий кореляційний зв'язок між розр хов ними коефіцієнт ми т відсотковою площею екологічного фонду міських територій. трим ні д ні свідч ть про доцільність використ ння з зн чених екогеогр фічних пок зників у системі генер льного пл нув ння з метою оптиміз ції перспективних рішень. 
лючові слов : урбол ндш фт, нтропогенне н в нт ження, пок зники

Introduction. One of the objectives of sustainable development strategy is to ensure ecologically safe land use, while in general the state of land resources of Ukraine is assessed as being close to critical (Khryshchuk and Bezpalko, 2013; Prykhodko, 2010). At present, the anthropogenic and technogenic impact on the natural environment in Ukraine is several times higher than the corresponding indicators of developed countries of the world (Khryshchuk and Bezpalko, 2013). A significant number of problems in the field of rational land use remain unresolved, the laws of ecologically safe nature management are violated, and anthropogenic impact is adversely affecting the sustainable development of land use.

In general, there are no virgin ecosystems left in the world. Our planet is a mosaic of ecosystems, from relatively intact, to completely rebuilt (Adler and Tanner, 2013). In the era of rapid urbanization, urban ecology has become the main environmental area, and the most important direction of its research is the sustainability of towns (Wu, 2014; Wilson, 2014). The tendency to create sustainable and stable towns is increasing; there is a unique opportunity to apply the results of scientific research in practice, to create environmentally clean towns of the future (McDonnell and Hahs, 2013). The stability of the towns depends to a large extent on the stability of the Earth, although the concept of sustainability remains neglected in modern urban planning (Ahern, 2011). It was precisely because of the concern for the sustainability of the towns that a new paradigm emerged - the ecology for the town, which increased the scale of research of urban ecosystems, and its important direction is the use of the theory of spatial urban heterogeneity as a key element of the town's functional activity (Pickett et al., 2016; Pickett et al. 2016a). In urban systems, the concept of environmental degradation has not yet been applied, except for the false but generally accepted assumption that urbanization itself is an obstacle, and therefore towns are permanently disturbed systems (Grimm et al., 2017).

Urbanization continues to be a global transformational process that affects the integrity of ecosystems, health and well-being of people. Despite the fact that towns as centers of production and consumption of goods and services worsen the natural environment, there is also evidence that urban ecosystems can play a positive role in ensuring sustainable development (McHale et al., 2015). Towns all over the world face an increasing diversity of problems, the solution of which should make them more sustainable (Childers et al., 2015).
The current land use system should include its study in certain areas, in particular environmental, which involves the creation of efficient land use in the following sequence: environmentally safe land use - economically feasible - socially significant (Khryshchuk and Bezpalko, 2013). No matter how the approaches to the implementation of the idea of sustainable development on a global scale are developed, the main node of problems and contradictions, the search for solutions to them lies in specific territories.

According to V. Kalmanova (2016), an ecological approach can only be used on the basis of strict environmental restrictions, which will allow the requirements for the preservation of the natural environment to be taken into account. At the same time, the system element can degrade or completely destroyed in order to take into account the interests of the global optimum. Currently, in the territorial planning system, predominantly, the urban development, rather than the environmental protection dominant, is preserved.

The environment changes under the influence of anthropogenic impact, which is characterized by changes in land use. The area of suburban zones is growing; urban infrastructure is expanding in rural areas. Modifications to land use lead to significant changes within the natural environment (Noszczyk et al., 2017). Regional differences in land use are the result of changes in anthropogenic impact on nature, as well as the impact of natural and social conditions of regions or settlements (Prus et al., 2017). Changes in socioeconomic, environmental, cultural and other conditions lead to global changes in the environment (Louca et al., 2015, Baśski and Mazur, 2016). Agglomeration is characterized by an unprecedented rate of residential development and the transformation of transport communications, which makes research into green plantations in the context of a rapidly changing urban environment relevant (Pogorelov and Lipilin, 2017).

Conceptual approaches to landscapeecological optimization of the territory, based on statements by I. Pozniak and N. Tsaryk (2013), include the implementation of a number of step-bystep measures, in particular the definition of landscape-ecological criteria and priorities for the development of regional economic systems, the achievement of optimal relationships between economic and natural lands, optimization of a biocentric-network structure of landscape systems - the natural channel of prospective ecological networks.

An urbanized area is a dynamic complex that 
is constantly expanding and needs to be ecologically balanced. The solution to this problem is impossible without the use of environmental assessment methods, analysis and forecasting of changes in the envi-ronmental situation (Kichata, 2013). Quantitative determination of spatial heterogeneity of land cover in urban systems plays a crucial role in the development of the ecological component of towns (Zhou et al., 2014). The method of quantitative estimation of integrated heterogeneity of urban areas has been proposed, involving rethinking approaches to the classification of urban land use and quantitative assessment of the urban landscape structure, which contains both built-up and unbuilt components (Cadenasso et al., 2007). The interrelation between the system of intensive land use and ecological safety of landscapes from the standpoint of urban sustainable development has been explored (Zhou et al., 2014). It has been noted that built-up areas are a major factor in the impact on environmental safety (Cen et al., 2015). By assessing landscape dynamic processes and analyzing long-term land-use trends, it is possible to obtain important spatial information for landscape planning and ecosystem management (Frelichova and Fanta, 2015).

A promising direction of geo-environmental research is the comparative analysis of the structure of land plots of administrative territorial units ( $\mathrm{Vo}-$ ronovich, 2016; Kochurov, 2003). Comparative studies of urban areas allow us to verify the suitability of conclusions and generalizations for towns with different social, historical and environmental conditions (Hahs et al., 2009). A model of urban sustainability is developed, based on long-distance comparisons, whose key goal is to take into account the processes by which towns become more sustainable (Childers et al., 2014). The conceptual framework for comparative research in different towns must also be developed (McPhearson et al., 2016). An assessment of the environmental sustainability of any territory is needed as a basis for developing proposals for its systemic economic and environmentally sustainable harmonious development (Glukhovskaia and Evstifeeva, 2016), sustainable land use planning (Getmanskii, 2013). The degree of environmental equilibrium depends not only on the area of green spaces, but also on the natural and economic characteristics of a particular town and its suburban zone, and the results of research on one town cannot be interpreted to characterize another (Narbut and Mirzekhanova, 2016). The statistical information can serve as the information base for research of the town structure $(\mathrm{Ny}-$ chaia and Tarasiuk, 2016). The predominance of anthropogenic-man-made, irreversibly altered landscapes in the town's structure indicates their unsta- ble state (Barmin and Nikulina, 2011). Instead, the underdeveloped spaces are a treasure and determine the overall ecological well-being of the territory not only of the town, but of the region and the country as a whole. Ecological lands should form the main link in the system of optimal organization of the territory (Narbut and Mirzekhanova, 2016).

In the conditions of intensification of nature use geosystems undergo increased anthropogenic impacts, which leads to destabilization of the ecological state of the territories and worsens the quality of life (Orlova et al., 2006). The development of sound methods of regional management of natural resources should be based on knowledge of the current state of the territory (Panchenko and Dyukarev, 2015). Aggravation of the problem of rational land use leads to an assessment of the ecological state of land use and the search for new scientific approaches to improve the criteria for optimizing them (Khryshchuk and Bezpalko, 2013). The intensity of land use can be characterized by such bioindicators as the coefficient of anthropogenic impact on the landscape and the ecological sustainability factor based on the categories of land use (Prus et al., 2017). The limitation is that the statistics are not spatially specific and do not provide qualitative information about the ecosystem (Frelichova and Fanta, 2015).

Ecological assessment of the territory is the basis of the development of environmental policies aimed at creating a sustainable nature management system (Kochurov, 1999). For the first time, the formula for assessing the ecological stability of the landscape was derived by Slovak scholars E. Clementov and V. Heinig (Glukhovskaia and Evstifeeva, 2016), and then actively used and improved by B. Kochurov and others. Currently, there are different approaches to the criteria and methods of environmental assessment of the territory (Khryshchuk and Bezpalko, 2013; Ivan and Chebenova, 2016), which is based on the ranking of land by nature and the level of human impact. More often geoecological estimation of the territory uses the coefficients of anthropogenic impact, ecological stability and natural protection of the territory (Bodrova, 2013), which allow one to determine the degree of balance of the land structure of the administrative-territorial unit and reflect the stability of natural systems. Unlike the index of tree cover and plowing area, the coefficient of natural protection is integral and can be used for a comprehensive assessment of the territory (Kochurov, 2003). The calculation of a complex integral indicator allows one to determine the potential of the environment, that is, the natural resource. The coefficient of ecological stability of urban territory is one of the indicators that enable one to evaluate the effectiveness of the existing 
system of greening of a town and to create a comfortable environment (Ivleva, 2015).

A common model of resource-preserving use of nature was developed by B. Kochurov's concept of ecological and economic balance of the territory, focused on balanced and environmentally safe territorial development taking into account specific landscape-environmental conditions (Kochurov, 2003; Minnikov and Kurolap, 2013). It is believed that the optimum ecological and economic status of the territory is characterized by the ratio of relative anthropogenic stress (Minnikov and Kurolap, 2013). An important element of the analysis of the current use of land resources in a particular territory is the definition of its anthropogenic transformation based on the correlation of land of different functional use in the general structure of the land fund of the region (Khryshchuk and Bezpalko, 2013), which is one of the most important components in the development of measures for systematic ecological management of the region, environmental policy and optimization of land use.

Comparative studies have different scales. Most geoecological studies are devoted to the assessment of the ecological balance of the regional territories (Getmanskii, 2013; Glukhovskaia and Evstifeeva, 2016, Khryshchuk and Bezpalko, 2013; Orlova, 2006; Prus et al., 2017), the territory of oblasts (Bodrova, 2013; Minnikov and Kurolap, 2013; Glukhovskaya, 2017), separate districts (Voronovich, 2016; Khryshchuk and Bezpalko, 2013), to a lesser extent - the study of urban areas (Ivleva, 2015; Kichata, 2013; Narbut and Mirzekhanova, 2016; Petrishchev and Dubrovskaia, 2013; Zibtseva, 2018).

Thus, there is a wide range of methods for determining the stability of territorial complexes of different rank, although, in our opinion, in essence, they do not have a fundamental difference: all are based on the definition of the quantitative (percentage or absolute) ratio between the different degrees of anthropogenic impacts on territories (ecologically stabilizing and ecologically destabilizing ) or on the determination of the share of economically stabilizing territories in the total area of the object. Unlike the post-Soviet space, we have not found such a wide differentiation by the names of coefficients in the works of European researchers, where they usually have the common name "coefficient of ecological stability" (Ivan and Chebenova, 2016). We consider it expedient to try different approaches to the possibility of their use for the assessment of urban areas, which taken as a complex should improve the quality of the analysis of the results.

The research is carried out within the framework of development of conceptual foundations of the system of green plantations in small towns of Kyiv region in the context of ecologically balanced development. The problems of sustainable development of small towns are among the most important issues discussed in the last decades by the world and European community (Bilokon, 2008). The majority of the population of the Kyiv region $(68.1 \%)$ lives in towns, twenty of them are small towns $(77 \%)$. This category is the most widespread and least studied. Intensive urbanization (especially in the metropolitan region) and the strategic course on sustainable eco-balanced development make research on the current state of small towns extremely relevant.

The purpose of the study is a comprehensive assessment of the ecobalance of the territories of three small towns of Kyiv region - Boyarka, Vyshneve and Irpin, with an analysis of the dynamics of ecological stability of the territories in the system of general planning.

Material and methods of research. For the analysis of the ecological balance of the territories of small towns, indicators of anthropogenic transformation and natural protection of the territory were determined, namely: coefficients of anthropogenic impact, anthropogenic transformation, nature conservation, environmental sustainability, ecological stability, absolute and relative tension of the ecological and economic condition of the territory of towns. To calculate the indicators, statistical data on the territory of towns (Form 6-Land) and publicly available data of the explanatory notes of the recently developed Master Plans of towns were used (Retrieved from http://boyarkainform.com/r_29_05_2014_

plan.html; http://vyshneve-rada.gov.ua/files/rada/18 /pz-gp-vyshneve.pdf; https://imr.gov.ua/forcitizens/generalnij-plan).

The towns investigated - Boyarka, Vyshneve and Irpin belong to the category of small towns, as their population is $34.6 ; 38.5$ and 41.5 thousand people, respectively, i.e. not more than 50 thousand people. The towns are located in the central part of the region, in the southwest direction from Kyiv: Vyshneve $-1.5-2 \mathrm{~km}$ from the ring road, Irpin $-15 \mathrm{~km}$, Boyarka - $23 \mathrm{~km}$ (Fig. 1) and are part of suburban metropolitan area. The towns are characterized by the same geological conditions (deluvial-eolian and eluvial deposits), in terms of tectonic zoning they are located on the Ukrainian shield, on the Kiev Plateau. According to agroclimatic zoning, the towns of Boyarka and Vyshneve belong to the Kiev highland region (the ForestSteppe zone), and the town of Irpin - to the area of Kyiv Polissya - territories of sufficient heat supply and moderate humidification. Living condi-

tions for the towns of Vyshneve and Boyarka are estimated as satisfactory, and for the town of Irpin - as moderately favourable. Vyshneve can be described as an industrial town, and Boyarka and 
Irpin - as multifunctional resort towns. According to the General Plans, the territorial resources of the towns within the existing limits are very limited: vacant ter-ritories for construction are almost absent; the existing construction is very dense. The proposals on prospective boundaries of towns fixed

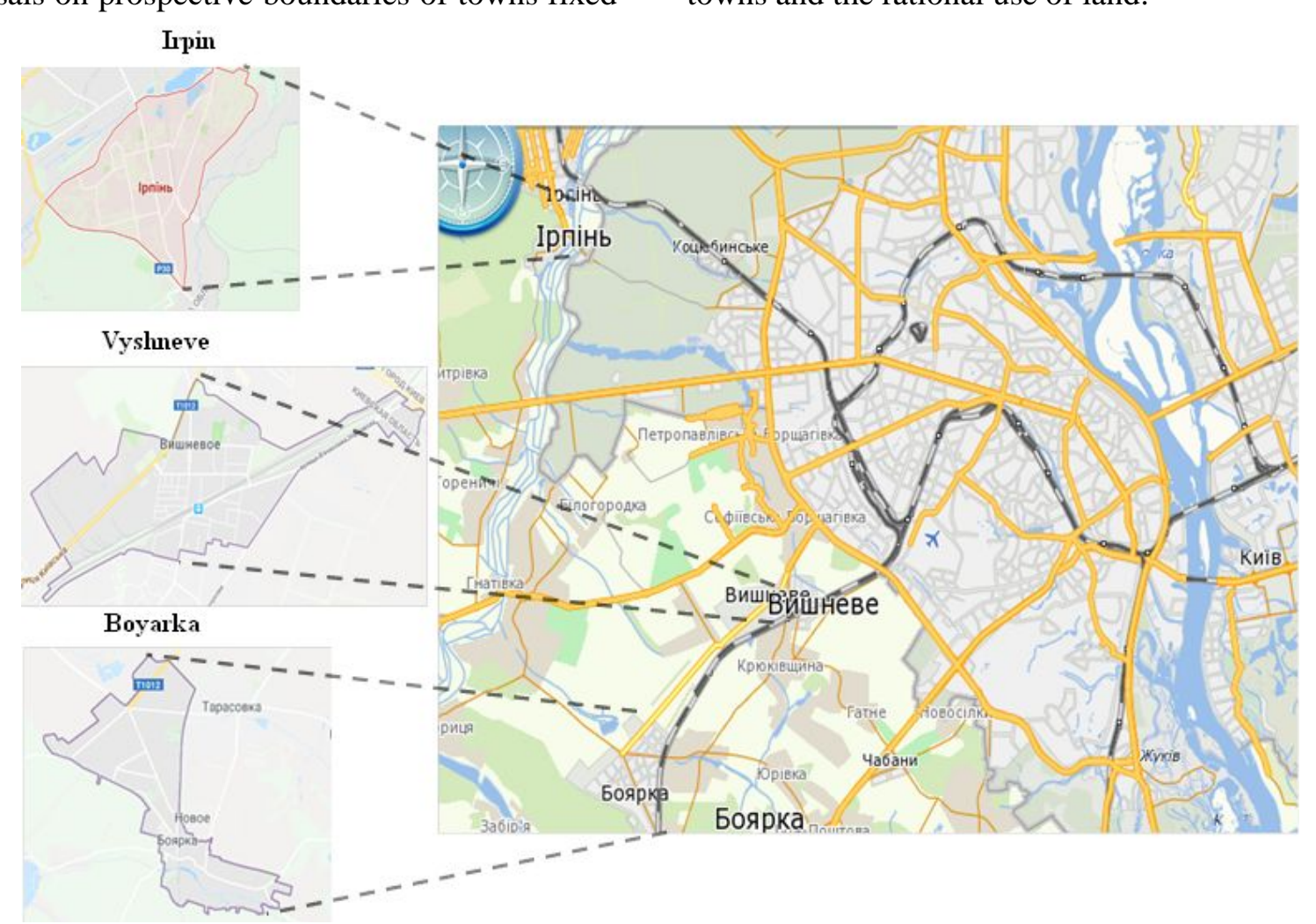

Fig. 1. Scheme of the location of the researchedtowns in relation to Kiev and the configuration of their territories

In order to assess the degree of balance of the territorial structure of towns, the integral indicators described by S. Volkov (2001) are used: the coefficients of ecological stability of the territory, the coefficient of anthropogenic impact. The assessment of the environmental fund and the coefficient of nature protection of the territory were carried out according to the method of B. Kochurov (2003). Types and categories of land in the general plans of the towns did not always coincide with the methods described, so the method of expert assessments of land use received points in accordance with the degree of anthropogenic transformation from low (1 - water surface and the territory of the nature reserve fund) to the highest $(5,6$ or 10 points - industrial land). The coefficient of anthropogenic impact was defined as the weighted average score on the existing areas of land of a certain type of land use and their relative scores; the coefficient of in the Master plans provide for the inclusion of additional territories at the expense of territories administered by councils of the neighboring villages. At the same time, the general plans declare the creation of a clearer zoning of the territories of towns and the rational use of land.

Table 1. Scale of assessment of ecological stability of the territory

\begin{tabular}{|c|c|c|c|}
\hline $\begin{array}{c}\text { Coefficient of environ- } \\
\text { mental sustainability }\end{array}$ & Ecological state & $\begin{array}{c}\text { Coefficient of anthropogenic } \\
\text { impact }\end{array}$ & $\begin{array}{c}\text { Level of anthropogenic } \\
\text { impact }\end{array}$ \\
\hline$\unlhd 0.33$ & Environmentally unstable & $4.1-5.0$ & High \\
\hline $0.34-0.50$ & Weakly stable & $3.1-4.0$ & Increased \\
\hline $0.51-0.66$ & Medium stable & $2.1-3.0$ & Average \\
\hline$\searrow 0.67$ & Environmentally stable & $1.0-2.0$ & Low \\
\hline
\end{tabular}


In order to assess the ecological and economic balance, the level of anthropogenic impact $(A I)$ was initially determined, for which, based on expert assessments, each type of land use, taking into account its ecological status, provided an appropriate point. Then, based on the calculation of the anthropogenic impact $\left(A I_{n}\right)$, the level of $A I$ for each territory was determined (Kochurov, 2003; Panchenko and Dyukarev, 2015) by the formula 1 :

$$
A I_{n}=r \cdot S_{r} \text {, }
$$

where $r$ - the point of anthropogenic impact; $S_{r^{-}}$ share of this category of land in the total urban area, $\%$.

The coefficients of absolute ( $a$ ) and relative $(r)$ stresses of the territory were calculated as the ratio of the area of land with high anthropogenic impact to the area with lower impact by the formula 2:

$$
K_{a}=\frac{A I_{6}}{A I_{1}},
$$

The value of the coefficient of absolute stress on the territory allows us to assess the situation by "marginal" criteria. For a more detailed analysis of the territorial balance according to the structure of land use and the natural-ecological potential, the ratio of the relative stresses of the territory ${ }_{r}$ was calculated on the ratio of 3 :

$$
K_{r}=\frac{A I_{4}+A I_{5}+A I_{6}}{A I_{4}+A I_{2}+A I_{3}},
$$

If $r$ is equal or closer to 1 , then the ecological and economic situation is estimated as balanced by the degree of anthropogenic impact and the potential of sustainability of nature. Territories which experience a high degree of anthropogenic impact have the lowest natural protection. If the area of the lands included in the ecological fund with a minimum $A I$ are taken as $P_{1}$, then the area of land with a conditional assessment of the degree of $A I$ in 2,3 and 4 points will be respectively $0,8 R_{2}, 0,6 R_{3}, 0,4 R_{4}$ (areas of high point of $A I$ are not included in the calculation) (Kochurov, 2003). Thus, the total area of land with environment and resource-stabilizing functions $\left(R_{e f}\right)$ was estimated by the formula 4 :

$$
P_{e f}=P_{1}+0,8 P_{2}+0,6 P_{3}+0,4 P_{4},
$$

where 0,$8 ; 0.6$ and 0.4 - corrective factors; $P_{1}, P_{2}$, $P_{3}$ and $P_{4}-$ lands included into the ecological fund with a conditional assessment of the degree of $A I$ in 1, 2, 3 and 4 points.

For the integrated assessment of the territory, the integral coefficient of natural protection $\left(K_{n p}\right)$ was used, which was determined by the formula 5 (Kochurov, 2003):

$$
K_{n p}=\frac{P_{e f}}{P},
$$

where - total area of the researched territory (town).

The value of the coefficient of natural protection of less than 0.5 indicates a critical level of protection of the territory.For estimation of the antrhropogenic transformation, the integral index (the index of regional human transformation of natural systems) of K. Hoffmann, specified in by P. Shishchenko (1999) and Khryshchuk and Bezpalko (2013) was calculated by formula 6 . The peculiarity of the calculation is to rank the land by 10 categories. In our studies in the towns there were 8 because no areas that belong according to the method to rank 3 (swamps and wetlands) and rank 9 (reservoirs, canals). The areas of the ranks were used in percentage indices and we calculated the depth of landscape transformation.

$$
K_{a t}=\frac{\sum_{I}^{n} r_{i} p_{i} a_{i}-}{100} .
$$

In the formula: $K_{a r}$ coefficient of anthropogenic transformation; $r$ - rank of anthropogenic transformation of the territory by a certain type of nature use; $p$ - area of rank, \%; $a$ - index of depth of transformation of landscapes; $n$ - number of types within the boundary of the region. In this technique, dividing by 100 is used for ease of use of the values of the coefficients. Each type of land use is assigned the rank of anthropogenic transformation and the index of the depth of transformation (Table 2), where the residential housing development was interpreted as rural, and multi-apartments - as a town.

Table 2. Ranks and indices of the depth of transformation of natural systems by different types of land use

\begin{tabular}{|c|c|c|}
\hline Types of land use & Rank of anthropogenic transformation & Index of depth of transformation \\
\hline Nature Reserve Territories & 1 & 1.00 \\
\hline Woods & 2 & 1.05 \\
\hline Swamps and wetlands & 3 & 1.10 \\
\hline Hay fields & 4 & 1.15 \\
\hline Gardens, vineyards & 5 & 1.20 \\
\hline Arable land & 6 & 1.30 \\
\hline Rural building & 7 & 1.35 \\
\hline Urban development & 8 & 1.40 \\
\hline Water reservoirs, canals & 9 & 1.50 \\
\hline Industrial use land & 10 & \\
\hline
\end{tabular}


Taking into account the considerable range of oscillations of the $K_{a t}$, a five-tier scale of its interpretation is used (Table 3), the content of which was the assessment of the ecological state of the landscape, as well as the classification of the ecological and economic status of the territory.

Table 3. Scale of anthropogenic transformation of a landscape The value of the coefficient of anthropogenic-technogenic

\begin{tabular}{|c|} 
transformation $K_{a t}$ \\
\hline $2.00-3.80$ \\
\hline $3.81-5.30$ \\
\hline $5.31-6.50$ \\
\hline $6.51-7.40$ \\
\hline $7.41-8.00$
\end{tabular}

Correlation relations between the calculated coefficients, as well as coefficients and share of the environmental fund in the total area of urban areas are established.

Results and their analysis. According to (Butrym, 2013), the built-up lands occupy $5.6 \%$ of the territory of the region (in 2010, together with the town of Kyiv) in the structure of the modern land use of the Kyiv region, and they are one of the most complex and most intensively growing types of anthropogenic landscapes.

Ranking of land use of the territory of the researched towns by the degree of anthropogenic impact is given in Table. 4, and the percentage of the modern and planned structure of urban lands by the degree of anthropogenic impact is illustrated by Fig.2.
Category of anthropogenic-technogenic transformation of the landscape Low transformed territory Transformed

Moderately transformed

Highly transformed

Excessively transformed
Fig. 2 indicates that the territory of the town of Irpin is the most balanced: in addition to the lands ranked at 1 point, which make up $3.3 \%$ of the total territory of the town, the remaining ranks make up almost equal proportions- from 22.7 to $26.2 \%$ of the urban territory. According to the planning, the area of land of grade 3 (due to towns and other lands) will be significantly reduced (down to $0.8 \%$ ), the area of land of rank 4 will increase (from 24.5 to $32.3 \%$ ) and the percentage of land of rank 1 will increase to $12.6 \%$ due to the expansion of the lands of the nature reserve fund. As a negative phenomenon from the point of view of the ecological balance of the territory, one can consider the prospective growth of the area of territory under heavy anthropogenic pressure ( ranks 4 and 5 ) from 50.7 to $57.0 \%$.

Table 4. Classification of land by the degree of anthropogenic impact

\begin{tabular}{|c|c|c|c|c|c|c|c|c|}
\hline \multirow{2}{*}{$\begin{array}{c}\text { Types and categories of } \\
\text { land }\end{array}$} & \multirow{2}{*}{ Point } & \multicolumn{2}{|c|}{ Boyarka } & \multicolumn{2}{|c|}{ Irpin } & \multicolumn{2}{|c|}{ Vyshneve } & \multirow{2}{*}{$*$} \\
\hline & & now & plan & now & plan & now & plan & \\
\hline $\begin{array}{l}\text { Residential apartment } \\
\text { buildings }\end{array}$ & 5 & 43.7 & 125.5 & 51.2 & 148.2 & 96.8 & 213 & 0.05 \\
\hline Houses with gardens & 4 & 426.0 & 567.5 & 724.3 & 909.8 & 67 & 97 & 0.5 \\
\hline $\begin{array}{l}\text { Enterprises, institutions, } \\
\text { establishments }\end{array}$ & 5 & 111.1 & 170.0 & 260.4 & 372.4 & 43.8 & 124 & 0.05 \\
\hline $\begin{array}{l}\text { Landscaped territories of } \\
\text { general areas of use GU** }\end{array}$ & 4 & 18.6 & 84.6 & 30.0 & 106.6 & 4.8 & 62 & 0.43 \\
\hline Streets, roads, squares & 5 & 186.0 & 221.0 & 145.7 & 246.0 & 102.1 & 237 & 0.03 \\
\hline Industrial area & 6 & 64.7 & 167.5 & 101.3 & 109.0 & 105 & 125 & 0.03 \\
\hline Municipal and warehouse & 5 & & & & & 190 & 200 & 0.03 \\
\hline Recreation bases & 4 & & & 106.2 & 146.0 & & & 0.05 \\
\hline Garden societies & 4 & 161.0 & 44.6 & 46.6 & 35.6 & & & 0.43 \\
\hline Cemeteries & 3 & 4.8 & 4.8 & 19.8 & 30.0 & & & 0.7 \\
\hline Waters, nature reserve fund & 1 & 10.9 & 10.9 & 122.4 & 466.0 & 0.5 & 2 & 0.79 \\
\hline $\begin{array}{l}\text { Beaches, gardens, swamps, } \\
\text { other }\end{array}$ & 3 & 12.3 & 12.3 & 820.7 & & 34.1 & & 0.1 \\
\hline Other green plantations & 2 & 61.7 & 262.1 & & 1098.5 & 60 & 91 & 1 \\
\hline Woods & 2 & 21.2 & 1718.2 & 962.0 & & & & 0.38 \\
\hline $\begin{array}{l}\text { Plots with start of construc- } \\
\text { tion }\end{array}$ & 5 & & & 314.5 & 37.0 & & & 0.03 \\
\hline Total & & 1122 & 3389 & 3705.1 & 3705.1 & 704.1 & 1151 & \\
\hline
\end{tabular}

Note: $\mathrm{K} *$ is the coefficient of ecological significance of the territory (Volkov, 2001; Glukhovskaia \& Evstifeeva, 2016); GU ** - landscaped territories of general use. In the town of Boyarka, in the category of "garden societies", taking into account the real specifics of the territories, the territory of the forest research station, the state institution "Ukrcentrcadrilliss", and the college garden are also classified. In the town of Irpin, the category of "recreation centers" includes the resort and recreational areas, and the category of "garden societies" includes agricultural areas. 

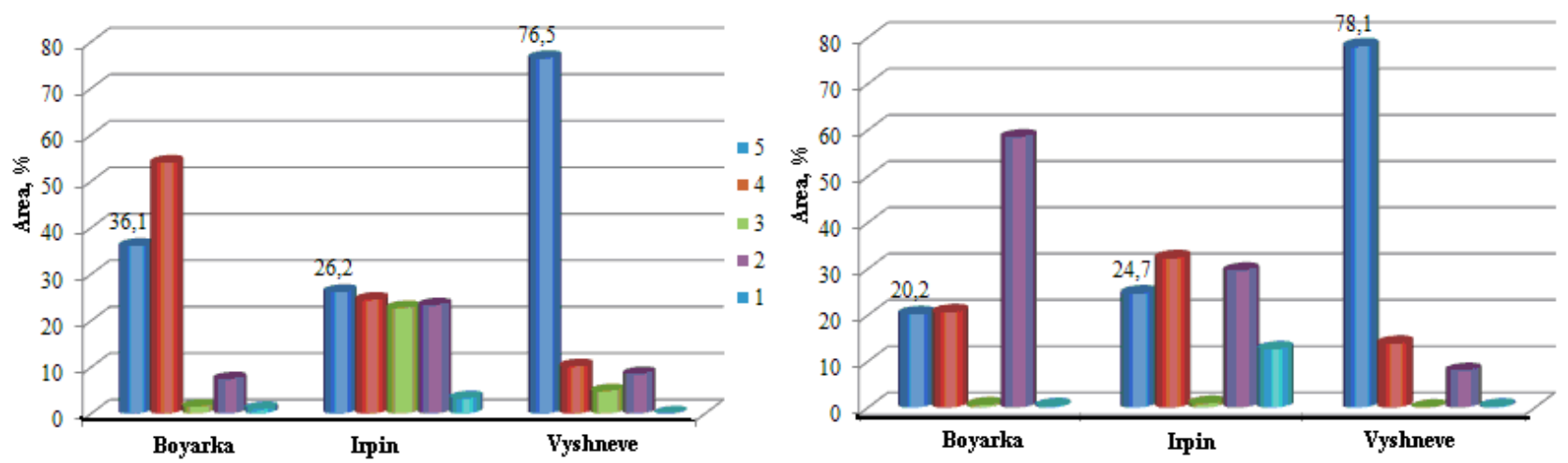

Fig. 2. Contemporary $(a)$ and planned $(b)$ structure of urban lands by the degree of anthropogenic impact (1 - 5 points), $\%$

On the territory of Boyarka, $90.1 \%$ of the lands are currently under heavy anthropogenic impact (ranks of land with 4 or 5 points), with rank 4 being the most widespread category of land (54\% of the territory), due primarily to the significant area of built- up land. The lands of rank 1 occupy only $1 \%$ of the town's territory. In the long term, according to the decisions of the general planning (according to which the town's area is three times larger, and the area of the attached forest is 1.5 times greater than the town's area at the time of the last master planning), the territory of the land of rank 2 will increase to $58.4 \%$ mainly due to the increase in the area of forests and the category "other green plantations". The percentage of land of rank 4 and rank 5 is redu-ced (to $20.2 \%$ and $20.6 \%$ respectively), but at the same time the percentage of land ranked at 3 points will decrease (to 0.5) and the percentage of land ranked at 1 point will decrease by almost three times (from 1 to $0.3 \%$ ). In general, for the overall urban area, such shifts appear to be positive.

The worst situation with the distribution of land is on the territory of the town Vyshneve. Both now and in the future, the most common category of land is the land rank with 5 points, the area of which is set to increase in the future (from 76.5 to $78.1 \%$ ), primarily due to the expansion of land for businesses, streets and squares, apartment buildings. The increase in the area of land rank with 4 points (from 10.2 to $13.8 \%$ ) will occur due to the creation of green spaces for general use. The area of land-ranking 1 point will increase to $0.2 \%$ and the area of land rank with 2 points in the structure of urban areas falls from 8.5 to $7.9 \%$, although in absolute terms this category of land area increases. Thus, despite the planned expansion by 1.6 times in the territory of Vyshneve town, according to the general plan this transformation will be accompanied by a further increase in anthropogenically impacted territories with ranks of 4 or 5 points and bringing their area in the structure of urban land from 86.7 to $91.9 \%$, and the share of land in the rank of 5 points will increase from 76.5 to $78.1 \%$. Thus, the cardinal expansion of the town's territory will be accompanied by a deterioration and lead to an environmentally unbalanced town territory. The calculation of the area of the environmental fund of urban areas is shown in Table 5.

Table 5. Calculation of the total area of the ecological fund for the territories of research small towns

\begin{tabular}{|c|c|c|c|c|c|c|c|}
\hline \multirow{2}{*}{ Coefficient } & \multirow{2}{*}{ Points } & \multicolumn{4}{|c|}{ The area of the ecological fund of small towns, ha } \\
\cline { 3 - 9 } & & \multicolumn{2}{|c|}{ Boyarka } & \multicolumn{2}{|c|}{ Irpin } & \multicolumn{3}{c|}{ Vyshneve } \\
\cline { 3 - 9 } & & now & plan & now & plan & now & plan \\
\hline 0.4 & 4 & 605.6 & 696.7 & 907.1 & 1198 & 71.8 & 159.0 \\
\hline 0.6 & 3 & 17.1 & 17.1 & 840.5 & 30.0 & 34.1 & 0 \\
\hline 0.8 & 2 & 82.9 & 1980.3 & 962.0 & 1098.5 & 60.0 & 91.0 \\
\hline 1 & 1 & 10.9 & 10.9 & 122.4 & 466.0 & 0.5 & 2.0 \\
\hline Total area, ha & & 1122.0 & 3389.0 & 3705.1 & 3705.1 & 704.1 & 1151.0 \\
\hline
\end{tabular}

We have calculated the coefficients of natural protection of the territories of towns at the time of development of their master plans and decisions of prospective general planning, which have the following values:

Boyarka: $K_{n p}=(10.9+66.32+10.26+242.24) /$ $/ 1122.0=329.72 / 1122.0=0.294$;

Boyarka (plan): $K_{n p}=(10.9+1584.24+10.26+$
$+278.68) / 3389.0=1884.08 / 3389.0=0.556$; Irpin: $K_{n p}=(122.4+769.6+504.3+362.84) /$

/3705.1=1759.14/3705.1 $=0.475$; Irpin (plan): $K_{n p}=(466.0+878.8+18+479.2) /$

$/ 3705.1=2112.0 / 3705.1=0.570$; Vyshneve: $K_{n p}=(0.5+48+20.46+28.72) /$ /704.1=97.68/704.1=0.139; Veshneve (plan): $K_{n p}=(2.0+72.8+0+63.6) /$ 

anthropogenic transformation of urban areas is shown in Table. 6

Table 6. Calculation of the coefficients of anthropogenic transformation for the territory of the researched towns

\begin{tabular}{|c|c|c|c|c|c|c|c|}
\hline \multirow{2}{*}{$\begin{array}{c}\text { Index of depth of transfor- } \\
\text { mation }\end{array}$} & \multirow{2}{*}{ Rank } & \multicolumn{3}{|c|}{ Area, \% } & \multicolumn{3}{c|}{ Vyshneve } \\
\cline { 3 - 8 } & & now & plan & now & plan & now & plan \\
\cline { 3 - 8 } & 10 & 22.34 & 11.46 & 6.67 & 9.58 & 56.40 & 48.82 \\
\hline 1.50 & 8 & 13.80 & 8.72 & 19.76 & 18.99 & 19.97 & 29.28 \\
\hline 1.35 & 7 & 37.96 & 16.75 & 19.55 & 24.55 & 9.52 & 8.43 \\
\hline 1.30 & 6 & 1.10 & 0.36 & 22.15 & 0 & 4.84 & 0 \\
\hline 1.25 & 5 & 16.01 & 3.81 & 2.07 & 3.84 & 0.68 & 5.39 \\
\hline 1.20 & 4 & 0.43 & 0.14 & 0.53 & 0.81 & 0 & 0 \\
\hline 1.15 & 2 & 7.39 & 58.44 & 25.97 & 29.65 & 8.52 & 7.91 \\
\hline 1.05 & 1 & 0.97 & 0.32 & 3.30 & 12.58 & 0.07 & 0.17 \\
\hline 1.00 & & & & &
\end{tabular}

Table 7 contains the values of the calculated eco-geographical indices for the territories of there- searched small towns and their approximate estimation relative to the norms.

Table 7. Eco-geographical coefficients of territories of the researched small towns

\begin{tabular}{|c|c|c|c|c|c|c|c|}
\hline \multirow{2}{*}{ Coefficient } & \multicolumn{2}{|c|}{ Boyarka } & \multicolumn{2}{|c|}{ Irpin } & \multicolumn{2}{|c|}{ Vyshneve } & \multirow{2}{*}{ Norm } \\
\hline & now & plan & now & plan & now & plan & \\
\hline Anthropogenic impact & 4.24 & 3.07 & 3.46 & 3.42 & 4.69 & 4.73 & $\leq 3$ \\
\hline Anthropogenic transformation & 0.91 & 0.41 & 0.71 & 0.58 & 0.91 & 0.92 & $\$ 1.65$ \\
\hline $\begin{array}{l}\text { Environmental sustainability of the } \\
\text { landscape }\end{array}$ & 0.09 & 1.42 & 0.41 & 0.73 & 0.09 & 0.09 & $\geq 1.01$ \\
\hline Ecological stability of the landscape & 0.24 & 0.27 & 0.19 & 0.39 & 0.12 & 0.12 & $\searrow 0.67$ \\
\hline Natural protection of the territory & 0.29 & 0.56 & 0.47 & 0.57 & 0.14 & 0.12 & $\searrow 0.5$ \\
\hline Absolute tension of the EEST* & 5.94 & 15.37 & 0.82 & 0.23 & 210 & 62.5 & 1 \\
\hline Relative tension of the EEST* & 18.94 & 1.58 & 1.72 & 2.94 & 13.80 & 28.26 & 1 \\
\hline Anthropogenic transformation & 9.52 & 5.68 & 7.30 & 6.74 & 12.07 & 11.74 & $2.00-3.80$ \\
\hline Area of the ecological fund, $\%$ & 29.4 & 55.6 & 47.5 & 57.0 & 13.9 & 12.0 & $57-70$ \\
\hline
\end{tabular}

Note: EEST * - the coefficient of ecological and economic status of the territory.

According to O. Shevchenko (2005), the land-resource potential of the Kiev region is decreasing, which negatively affects the quality and quantity of other natural resources. At the same time, during the period from 2008 to 2014 , the area of built-up land increased by 12.6 th.ha , by $0.5 \%$ and amounted to $4.8 \%$ of the total area of the region. It is noted that the Kyiv region has low indicators on the level of providing land for recreational purposes and natural and recreational resources (the share of land for recreational purposes does not exceed $0.1 \%$ ) and re-quires the introduction of environmental principles of recreational nature management (Poltavets, 2013).

Among the priority directions of the development of the territory of the suburban zone of Kyiv, which includes the territory of the researched towns, the general planning presupposes the preservation of a common landscape and recreational system of green spaces, at the same time it is planned to relocate a number of industrial enterprises outside Kyiv, in particular resource-intensive and ecologically harmful, to use the territory of the suburban area for the placement of residential lowrise and multi-storey buildings, communal, industrial, transport and warehouse facilities, which can lead to admiral urbanization of territories. In particular further urbanization of Vyshneve and Boyarka , is foreseen as centers of neighboring district settlement and recreation systems (http://kievgenplan.grad.gov.ua/ua/tekstovi -materiali/15-generalny-plan/76.html).

According to Y. Bilokon, the general plans of small towns should be directed, first of all, to search for territorial resources to increase their sustainability and attractiveness for business and tourism, strictly limiting the sources of environmental and technological danger (Bilokon,2008); in this case, small towns in the future can become the basis for harmonization of social life, social stability and cultural revival of our society.

Our calculations have shown that the coefficient of anthropogenic impact of the researched small towns currently corresponds to the mean value in the region of 3.4 only for the territory of Irpin and is moderate, and for the other two towns, especially for Vyshneve, significantly exceeds the mean value in the region and corresponds to a high anthropogenic impact. For comparison, the magnitude of the anthropogenic impact coefficients for other small towns of Kyiv region - Ukrainka and Obukhov - is respectively 2.78 and 3.66 , and for the pre- 
viously investigated historical town of Vyshhorod 3.71 , which corresponds to the elevated level. Realization of the planned measures for the researched towns will allow reduction of the anthropogenic impact on the territory of Boyarka (to a moderate level) and also to some extent in the territory of Irpin, but will to some extent raise the already high anthropogenic impact on the territory of Vyshneve.

High values of the coefficient of anthropogenic transformation and low coefficient of environmental sustainability of the landscape (pronounced instability) are characteristic of the current state of Boyarka and Vyshneve. Improvement of the prospects for Boyarka will take place through the expansion of the town's territory by three times (encompassing mostly adjacent forest lands), resulting in the Boyarka territory being characterized as conditionally stable. The territory of Irpin will remain unstable, but the situation with this indicator will improve almost twice. For Vyshneve, improving the situation in the calculation period (until 2030) is not expected, and anthropogenic transformation will increase.

The ecological stability of the landscape in the existing boundaries of the towns varies from 0.12 (Vyshneve) to 0.24 (Boyarka), that is, the territories of all towns are environmentally unstable. In the long run, only the territory of Irpin will become unstable. For the territory of Vyshneve this indicator will not improve its position.

The total area of the environmental funds of the towns is currently $13.9 \%$ of the urban area of Vyshneve, $29.4 \%$ of Boyarka and $47.5 \%$ of the territory of Irpin, which according to the data (Poltavets, 2013) accounts for $15.39 \%$ of the regional land for recreational purposes. According to the general plans of the towns, the area of the environmental fund of Boyarka and Irpin will approach the optimal value and will accordingly be 55.6 and 57.0\%. In Boyarka, such an optimization will take place due to the expansion of the urban area (almost 1.7 th.ha of forests will be added), and in Irpin due to an increase of more than 0.3 th.ha of the nature reserve fund area and the appearance of 1.1 th.ha other green plantations, which, however, will be accompanied by the disappearance of 962 hectares of forest lands. The area of the ecological fund of Vyshneve, in spite of the 1.6 times expansion of the town's territory, and contrary to the declared objective of ecologically balanced land use, will decrease by $1.9 \%$ to $12.0 \%$. The coefficient of natural protection of the territory is currently the most critical for the territory of Vyshneve, although for all three towns this is less than 0.5 , which indicates the critical level of protection of the territories of the researched small towns within their existing urban boundaries. In the case of general planning, the coefficient of natural protection of the Boyarka and Irpin areas will increase to 0.56 and 0.57 , which will correspond to high natural-ecological potential and resistance to anthropogenic impacts. Instead, the level of protection of the territory of Vyshneve will remain critical, and the coefficient of natural protection of the territory will deteriorate from 0.14 to 0.12 .

Thus, the current territories of the researched small towns have a low degree of favourableness (Voronovich, 2016) of the territory (in all cases , a moderate or high anthropogenic impact is combined with a critical value of the coefficient of natural protection).

Significant changes are observed in the absolute and relative tensions of the ecological and economic status of the territories of the researched towns. At present, according to these indicators, the situation is closer to the optimal one only in Irpin, but in the long run even here it will sometimes deteriorate. The coefficient of absolute tension of the ecological and economic status of the Vyshneve is 210 times the optimal value, but according to the plan it is to be doubled, whereas the relative intensity of the ecological and economic condition of the territory will be halved in terms of the plan. The relative intensity of the ecological and economic condition of the territory is currently the highest for Boyarka, but according to the plan it is most important to approach the optimum value. The coefficients of relative anthropogenic stress indicate an unbalanced ecological and economic condition of the urban areas both at the present stage and in the future. High values of the absolute ecological stress factors indicate an unfavourable geoecological situation in the studied territories and justify the need to create a stabilizing environment in the region under research.

According to general planning, the coefficient of anthropogenic transformation of the territory will change from the excess to the average for Boyarka, will remain high for Irpin and excessive for Vyshneve, but with minor positive shifts in both cases.

Between the area of the ecological fund with calculated geoecological indicators (coefficients) a rather high and mostly reliable correlation relationship was determined: the coefficients of correlation vary from $0.86 \pm 0.258 ; \mathrm{P}=0.95$ (coefficient of ecological stability of the landscape) and $-0.67 \pm$ 0.370 (absolute tension of the ecological and economic condition of the territory, the relationship is unreliable) to $-0.98 \pm 0.097 ; \mathrm{P}=0.99$ (coefficient of anthropogenic pressure), $-0.99 \pm 0.082 ; \mathrm{P}=0.99$ (anthropogenic transformation) and 1.00 (coefficient of natural protection of the territory). The closest negative correlation is observed, naturally, 
between the coefficient of natural protection of the territory and the coefficients of anthropogenic impact and anthropogenic transformation $(r=-0.99$ in both cases), and positive - between the coefficient of anthropogenic impact and anthropogenic transformation $(r=0.99)$.

Conclusions. The analysis of the territorial structure of the three small towns of Kyiv region indicates the diversity of trends in the ecological balance of their territories and the feasibility of using ecogeographic indicators in the system of general planning in order to optimize prospective design decisions. The town Irpin is characterized by an average degree of environmental favourableness and its territory is now ecologically more balanced. The territories of Boyarka and Vyshneve have a low degree of favourableness (high level of anthropogenic impact and critical value of the coefficient of natural protection). The analysis of the master plan has shown that the ecological situation will be dramatically improved in the territory of the town of Boyarka due to the threefold expansion of the town boundaries. Instead, the extension by 1.6 times of the boundaries of Vyshneve does not provide for improvement of the ecological balance of the town. In order to ensure the sustainable development of urban areas in general planning we consider it expedient to take into account not only urban, economic and social, but also environmental factors, to link them to a single principle of environmentalization of territories. Proposed measures in the general plans should ensure the strengthening of the natural basis of towns and increase environmental sustainability, which is justified by calculations of integral indicators: the factors of ecological stability of the territory, anthropogenic impact, natural protection of the territory.

\section{References}

Adler,F. R.,Tanner, C. J. (2013). Urban ecosystems: ecological principles for the built environment. Cambridge University. Press, Cambridge, UK. https://doi.org/10.1017/CBO9780511981050

Ahern, J. (2011). From fail-safe to safe-to-fail: sustainability and resilience in the new urban world. Landscape and Urban Plannin, 100, 341343. https://doi.org/10.1016/j.landurbplan.2011. 02.021)

Bacski, J., Mazur, M. 2016. Classification of rural areas in Poland as an instrument of territorial policy. Land Use Policy, 54, 1-17. https://doi.org/10.1016/j.landusepol.2016.02.005 3.

Barmin A. N., Nikulina E. M. (2011). Rol landshaftnogeograficheskogo podkhoda $\mathrm{V}$ postroenii ekologicheskogo karkasa gorodov [Significance of landscape and geographical approach in creation of ecological framework of cities].
Geologiia, geografiia i globalnaia energiia, 4 (43), 168-174 (in Russian).

Bilokon, $\mathrm{Yu}$.

(2008).

Mistobudibnyproblemystalohorozvytku malyh mist Ukrainy [ArchitecturalproblemsofstabledevelopmentofUkrainiansmalltowns] Ukrainian). Retrieved from http://www.nbuv.gov.ua/dprmu/2008_15/1_Bilok on.pdf

Bodrova, V. N. (2013). Raschet i otcenka ekologokhoziaistvennogo balansa Volgogradskoi oblasti $\mathrm{v}$ geoinformatcionnoi sisteme [Estimation and assessment of ecological and economic balance of the Volgograd region]. Problemi regionalnoy ekologii, 2, 43-50 (in Russian).

Butrym, O. V. (2013). Struktura zemelnykh resursiv Kyivskoi oblasti ta optymizatsiia yikh vykorystannia [Structure of land resources of the Kiev region and optimization of their use]. Zbalansovane pryrodokorystuvannia. Zemlekorystuvannia, 2-3, 83-88 (in Ukrainian).

Cadenasso, M. L., Pickett, S. T. A., Schwarz, K. (2007). Spatial heterogeneity in urban ecosystems: reconceptualizing land cover and a framework for classification. Frontiers in Ecology and the Environment, 5, 80-88. https://doi.org/10.1890/ 1540-9295(2007)5[80:SHIUER]2.0.CO;2

Cen,X., Wu, C., Xing, X., Fang, M., Garang, Z., Wu, Y. (2015). Coupling Intensive Land Use and Landscape Ecological Security for Urban Sustainability: An Integrated Socioeconomic Data and Spatial Metrics Analysis in Hangzhou City. Sustainability, 7, 1459-1482, doi:10.3390/ su7021459

Childers, D. L., Cadenasso, M. L., Grove J. M., Marshall V., McGrath, B., Pickett, S. T. A. (2015). An ecology for cities: a transformational nexus of design and ecology to advance climate change resilience and urban sustainability. Sustainability,7(4), 3774-3791; https://doi.org/10.3390/su 7043774.

Childers, D. L., Pickett, S. T. A., Grove J. M., Ogden L., Whitmer, A. (2014). Advancing urban sustainability theory and action: challenges and opportunities. Landscape and Urban Planning, 125, 320-328. https://doi.org/10.1016/ j.landurbplan.2014.01.022.

Frelichova, J., Fanta, J. (2015). Ecosystem service availability in view of long-term land-use changes: a regional case study in the Czech Republic Journal. Ecosystem, Health and Sustainability, $1, \quad 10$. https://doi.org/10.1890/EHS15-0024.1.

Getmanskii, M. Iu. (2013). Otcenka sbalansirovannosti struktury zemlepolzovaniia $\mathrm{V}$ Adygee dlia generalnogo planirovaniia [Assessment of a balance of the land-utilization structure in Adyghea for general planning]. Vestnyk AGU, Estestvenno-matematicheskie i tekhnicheskie nauki,2, 120-128 (in Russian).

Glukhovskaia, M. Iu. (2017). Analiz ekologicheskoi ustoichivosti i stabilnosti regionalnoi territorii na 
primere Orenburgskoi oblasti [Theanalysis ofecologicalresistanceandstabilityofregionalterritory (on the example of Orenburgregion)]. Vestnik Orenburgskogo gosudarstvennogo universiteta, 4, 53-61 (in Russian).

Glukhovskaia, M. Iu., Evstifeeva, T. A. (2016). Analiz ustoichivosti regionalnykh territorii (na primere otdelnogo raiona Orenburgskoi oblasti) [Theanalysis ofstabilityofregionalterritories (on the example of separatedistrictofOrenburgregion)] Universitetskii kompleks kak regionalnyi tcentr obrazovaniia, nauki i kultury, OGU, Orenburg, 779-785 (in Russian).

Grimm, N. B., Pickett, S. T. A., Hale, R. L., Mary, L. (2017). Does the ecological concept of disturbance have utility in urban social-ecologicaltechnological https://doi.org/10.1002/ehs2.1255)

Hahs, A., McDonnell, M. J., Breuste, J. (2009). A comparative ecology of cities and towns: synthesis of opportunities and limitations. Ecology of cities and towns: a comparative approach. Cambridge University Press, New York, USA, 574-596. https://doi.org/10.1017/CBO9780511609763.036)

Ivan, P., Chebenova, T. (2016). Assessment of the ecological stability of the Village of Bielovce as a result of to changes in land use. Slovak Journal of Civil Engineering, 24, 2, 1-6. doi: 10.1515/sjce2016-0006

Ivleva, A. N. (2015). Otsenka effektivnosti organizacii sistemy ozeleneniya gorodov Nizhegorodskoy oblasti [The evaluation efficiencyof organization of landscaping system cities in Nizhny Novgorod region]. Nizhegorodskiy ASU, Nizhny Novgorod (in Russian).

Kalmanova, V. B. (2016) Ekologicheskii karkas urbanizirovannykh territorii na primere goroda Birobidzhana [The ecological framework of the urbanized territories (on the example of Birobidzhan city)]. Institut kompleksnogo analiza regionalnykh problem DVO RAN Birobidzhan, Birobidzhan, 385-388 (in Russian).

Khryschuk, S. Yu., Bespal'ko, R. I. (2013). Antropohenna peretvorenist yak kryterii optymizatsii zemlekorystuvan na rehionalnomu rivni [Anthropogenic transformation as a criterion of optimization of land-tenures at regional level].Science and Education a New Dimension: Natura and Technical Sciences, 1(2), 15, 138141(in Ukrainian).

Kichata, N. (2013). Analiz otcenki ekologicheskogo sostoianiia gorodskoi territorii [Analysis ofenvironmentalassessmentofurbanareas], Kiev, NAU(in Russian). Retrieved from er.nau.edu.ua/bitstream/NAU/29039/1/ pdf

Kochurov, B. I. (1999). Geoekologiia: ekodiagnostika i ekologo-khoziaistvennyi balans [Geoecology, ecodiagnostics and ecological and economic balance]. SGU, Smolensk, 154. (in Russian).
Kochurov, B. . (2003). Ekodiagnostika i sbalansirovannoe razvitie [Ecological diagnostics and balanced development]. Madzhenta, Moscow, Smolensk, 384. (in Russian).

Kovalchuk, . Y. (2016). Ekologo-khoziaistvennyi balans territorii Aulie Respubliki Kazakhstan i ee estestvennaia zashchishchennost [Ecological andeconomical balance of the area of Auliecol district of the Republic of Kazakhstan and its natural protection] (in Russian). DOI 10.21661/r113349

Kurhanevych, L., Shipka, M. (2012). Vyznachennia ekolohichnoi stiikosti heokompleksiv baseinu richky Poltvy [The estimation of ecological resistance of geocomplexes of the Poltva river basin]. Konstruktyvna heohrafiia i heoekolohiia. Naukovi zapysky, Ternopil, 2 (in Ukrainian).

Louca, M., Vogiatzakis, I.N., Moustakas, A. (2015). Modelling the combined effects of land use and climatic changes: Coupling bioclimatic modelling with Markov-chain Cellular Automata in a case study in Cyprus. Ecological Informatics, 30, 241249. https://doi.org/10.1016/j.ecoinf.2015.05.008

McDonnell, M. J., Hahs, A. K.. (2013). The future of urban biodiversity research: moving beyond the "low-hanging fruit". Urban Ecosystems, 16, 397409. doi:10.1007/s11252-013-0315-2.

McHale, M. R., et al. (2015).The new global urban realm: complex, connected, diffuse, and diverse social-ecological systems. Sustainability, 7, 5211-5240. https://doi.org/10.3390/su7055211

McPhearson, T., Pickett, S. T. A., Grimm, N., Niemela, J., Alberti, M., Elmqvist, T., weber, C., Breuste, J., Haase, D., Qureshi, S. (2016). Advancing urban ecology towards a science of cities. BioScience, 66, 198-212. http://dx.doi.org/10.1093/biosci/ biw002.

Minnikov, I. V., Kurolap, S. A. (2013). Otcenka ekologo-khoziaistvennogo balansa territorii Voronezhskoi oblasti [Assessment of ecological and economic balance in Voronezh oblast]. Vestnik VGU, Geografiia. Geoekologiia, 1, 129136 (in Russian).

Narbut, N. A., Mirzekhanova, Z. G. (2016). Osobennosti ekologicheskogo planirovaniia gorodskoi territorii $\mathrm{v}$ regionakh novogo osvoeniia (na primere Khabarovska) [Specificofecologicalplanningintheregionsofnewdevelopment (Khabarovskcityasanexample)]. MaterialimezhdunarodnoikonferentsiiInterKarto/InterGIS，20，600-605 (in Russian).

Noszczyk, T., Rutkowska, A., Hernik, J. (2017). Determining Changes in Land Use Structure in Maiopolska Using Statistical Methods. Polish Journal of Environmental Studies, 26, 1, 211220. https://doi.org/10.15244/pjoes/64913

Nychaia, O. O., Tarasiuk, N. A. (2016).Selitebni landshafty $\mathrm{v}$ strukturi uhid vysochynnoi oblasti Volyni [The inhabited landscapes in the land structure of Volyn region upland area]Dnipropetrovsk University Bulletin. Series 
geology, geography. 2016, 24(1), 112-119 (in Ukrainian). doi: 10.15421/111617

Orlova, I. V., Rybkina, I. D., Stoiashcheva, N. V. (2006). Otcenka integralnoi antropogennoi nagruzki na territoriiu Altaiskogo kraia [Assessment ofintegralanthropogenicloadonterritoryofAltaikrai]. Polzunovskii vestnik, 4-2, 123-130 (in Russian).

Panchenko, E. M., Dyukarev, A. G. (2015).Otsenka ekologo-khoziaistvennogo balansa Ob-Tomskogo mezhdurechia $\mathrm{s}$ uchetom antropogennoi nagruzki[Assessment of ecological and economical balance of the territory of Ob-Tom interfluve concidering antropogenic load].Izvestiia Tomskogo politekhnicheskogo universiteta Inzhiniring georesursov, 326, 12, 8795 (in Russian).

Petrishchev, V. P., Dubrovskaia, S. A. (2013). Metodika kompleksnoi otcenki ekologicheskogo sostoianiia gorodskikh territorii [Method ofcomprehensiveenvironmentalassessmentofurbanareas]. IzvestiiaSamarskogonauchnogotsentraRAN, Problemy prikladnoi ekologii, ISU RAN, Orenburs, 15, 3, 234-238 (in Russian).

Pickett, S. T. A,Candenasso M. L., Childwrs, D. L., Mcdonnell, M. J., Zhou, W (2016). Evolution and future of urban ecological science: ecology in, of, and for the city. Journal Ecosystem Health and Sustainability, 2, 7. https://doi.org/10.1002/ehs2. 1229)

Pickett,S. T. A., Grimm, N., Niemel, J., Alberti, M., Elmqvist, T., Weber, C., Breuste, J., Haase, D., Qureshi, S. (2016a). Advancing urban ecology towards a science of cities. BioScience, 66, 198212. http://dx.doi.org/10.1093/biosci/biw002

Pogorelov, A., Lipilin, D. (2017).Zelenye nasazhdeniia goroda Krasnodara. Otsenka I mnogoletnie izmeneniia [Green spaces of Krasnodar city. Evaluation and multy-year changes].Vestnik PNIPU, Prikladnaia ekologiia, Urbanistika, Kuban, 3 (in Russian). doi: 10.15593/24095125/2017.03.15

Poltavets, A. M. (2013). Aktualni pytannia zberezhennia rekreatciinoho potentsialu Kyivskoi oblasti [RelevantquestionsofretentionofrecreationalpotentialofKyiv region]. Visnyk Sumskoho NAU, 6 (57), 162-166 (in Ukrainian).

Pozniak, I., Tsaryk, N. (2013). Pidkhody shchodo zbalansovanogo rozvytku mista (na materialakh m. Ternopolia) [An approach to balanced development city (on the materials from Ternopil)]. Konstruktyvna heohrafiia i heoekolohiia. Naukovi zapysky, Ternopil, 2, 213219 (in Ukrainian).
Prus, B., Bacior, S., Dudzinska, M. (2017). Assessment of historical bio-index changes in rural areas in Southern Poland - case study. Proceedings of the 8th International Scientific Conference Rural Development. http://doi.org/10.15544/RD.2017.012.

Prykhodko, M. M. (2010). Ekobezpeka pryrodnykh ta antropohennykh heosystem: problemy, tsili, priorytety [Ecological safety of natural and anthropogenic geosystems: problems, aims, advantages]. Naukovi zapysky Ternopilskoho NPU, Ternopil, 1(27), 96-100 (in Ukrainian).

Shevchenko, O. V. (2015).Ekolohoekonomichniistansylskohospodarskohozemlekory stuvanniaKiivskoioblasti[Ecological andeconomic stateofagriculturallandutilizationinKyivregion].Ekonomikataekolohiia zemlekorystuvannia, 2/3, 90-100(in Ukrainian).

Shishchenko, P. G. (1999). Printcipy i metody landshaftnogo analiza $\mathrm{V}$ regionalnom proektirovanii [Principles and methods of landscape analysis are in the regional planning]. Fitosotciotcentr, Kyiv, 284 (in Russian).

Volkov, S. N. (2001) Zemleustroistvo. Zemleustroitelnoe proektirovanie. [Land management], Moscow, Kolos, 2, 648 (in Russian).

Voronovich, E. N.(2016). Podkhody k otcenke ekologokhoziaistvennogo balansa zemel Drogichinskogo raiona [Approaches to assessment of ecologicalandeconomicbalanceoflandofDrogichinskiydistrict]. Ustoichivoe razvitie regionalnye aspekty, Brestskii GU, Brest,49-52 (in Russian).

Wilson, G.(2014). Urban ecology: advancing science and society. Frontiers in Ecology and Environment, $\quad 12, \quad 574-581$. https://doi.org/10.1890/140019)

Wu, J. (2014).Urban ecology and sustainability: The state-of-the-science and future directions. Planning, 125, 209-221.https://doi.org/10.1016 /j.landurbplan.2014.01.018

Zhou, W., Cadenasso M. L., Schwarz, K., Pickett, S. T. A. (2014). Quantifying spatial heterogeneity in urban landscapes: integrating visual interpretation and object-based classification. Remote Sensing, 6(4), 3369-3386. https://doi.org/10.3390 /rs6043369

Zibtseva, O. V. (2018). Shchodo ekozbalansovanosti teritirii maloho mista [About ecological balance of the small town territory]. Naukoviy visnyk NUBiP Ukrainy(in Ukrainian). 